\title{
General Review on Crimes in the Capital Market Sector
}

\author{
$1^{\text {st }}$ Farah Gitty Devianty \\ Fakultas Hukum \\ Universitas Langlangbuana \\ Indonesia \\ farahgitty12@gmail.com
}

\author{
$2^{\text {nd }}$ Widjajani \\ Fakultas Teknik \\ Universitas Langlangbuana \\ Indonesia
}

\author{
$3^{\text {rd }}$ E Dwipriyoko \\ Fakultas Teknik \\ Universitas Langlangbuana \\ Indonesia
}

\begin{abstract}
In the economic development in Indonesia, interesting activities have emerged, one of which is the capital market. The capital market has a strategic role in national development as a source of financing in the business world and a place for community investment, where entrepreneurs and the community can collaborate for the creation of economic stability in the business world. But in practice, some criminal acts and violations occur in the world of capital markets. As we know, activities in the economic sector are not immune to crimes committed by irresponsible parties. So the public needs to know how the legal aspects are related to crime in the capital market.
\end{abstract}

Keywords-Crimes, Capital, Market

\section{A. Background Study}

\section{INTRODUCTION}

The development of the economy in Indonesia have many interesting things have emerged, one of which is the capital market. The capital market has a strategic role in national development as a source of financing in the business world and a place for community investment, where entrepreneurs and the community can collaborate for the creation of economic stability in the business world. But in practice, some criminal acts and violations occur in the world of capital markets.

To carry out this strategic role, the capital market needs to be supported by adequate infrastructure, a strong legal framework, and a professional attitude from capital market players. For this reason, the government facilitates this by the enactment of Law Number 8 of 1995 concerning the Capital Market.[1]

The capital market can be said is a meeting place for people who need capital with people who want to buy capital. People here are certainly people in the sense of legal subjects, that is, individuals or other legal entities, such as a Limited Liability Company, for example. In the Indonesian capital market, there are organizers, namely the Indonesia Stock Exchange (IDX), supervisors, namely the Financial Services Authority (OJK), and there are parties who need capital that will issue shares/securities called issuers or the one that got invest, and those who are willing to buy capital which is usually called an investor. Capital that is sold is in the form of shares, bonds, warranties, securities, and other products that are often referred to as securities.[1]

The capital market (capital market) brings together the owner of the fund (supplier of funds) with the user of the fund (user of funds) for medium-term and long-term investment. UUPM (Undang-Undang Pasar Modal) [12] article 1 number 13 defines: The capital market is an activity that is related to the Public Offering and Trading of Securities of Public Companies relating to the issuance of securities, and institutions and professions related to securities.

The Indonesian government, through BAPEPAM, strives to overcome and prevent crime in the Indonesian capital market by various ways between disciplining and fostering capital market players as a preventive measure and resolving crime in the capital market sector as a repressive measure.

The tasks carried out by BAPEPAM are not easy, therefore BAPEPAM is given the authority to conduct investigations, examinations, investigations and continue prosecution to the prosecutor for the alleged crime. For violations, BAPEPAM has the authority to carry out investigations, investigations and administrative sanctions.[2]

\section{B. Problem Identification}

Departing from the background of problems relating to crimes that occur in the capital market, in it also relates to economic development in the community, where there are components such as the capital market, shares, business actors, publicly listed companies and where the implementation structured, then the formulation the 
problem is: "What about the legal aspects of crime in the capital market?"

The development of the economy in Indonesia have many interesting things have emerged, one of which is the capital market. The capital market has a strategic role in national development as a source of financing in the business world and a place for community investment, where entrepreneurs and the community can collaborate for the creation of economic stability in the business world. But in practice, some criminal acts and violations occur in the world of capital markets. Then the next problem formulation is "what is the category of crime in the capital market?"

\section{Research Method}

The method used in this research is a qualitative approach with normative juridical aspects, namely testing and reviewing secondary data, namely the principles contained in legislation relating to the general review of crimes in the capital market and law enforcement aspects in the field of capital market crime.

\section{LITERATURE REVIEW}

The State of Indonesia is a state of law and is not based on mere powers, this is reflected in the provisions of Article 1 paragraph (3) of the 1945 Constitution 4th Amendment, which states: "The State of Indonesia is a state of law".[3]

The law is the command of the authorities, in the sense that orders from those who hold the highest authority or from those who hold sovereignty, such as laws, government regulations and others are referred to as positive law.[4]

In every country that adheres to the rule of law, three basic principles are visible, namely the supremacy of law, equality before the law, and law enforcement in a way that is not contrary to the law (due process of law). That the law with the noble aim can only be realized well, if it fulfills 5 (five) factors as stated by Soerjono Soekanto.[5] The basis for capital market activities is regulated in Law Number 8 of 1995 concerning Capital Markets, which is contained in Republic of Indonesia State Gazette 1995 Number 64 which was approved by the Parliament on 2 October 1995, endorsed by the president 10 November 1995 and entered into force on 1 January 1996.

Law Number 8 of 1995 supersedes Law Number 15 of 1952 which stipulates the enactment of Emergency Law
Number 13 of 1951 as law. Criminal sanctions covered by Emergency Law Number 52 of 1951 are still light.[6]

\section{DISCUSSION}

\section{A. Capital Market Crime}

The current condition in the world capital market many crimes and violations occur. This happens due to several factors, namely misunderstanding and mistakes of the perpetrators. Unclear action from the authorities and legislation that is not yet completely regulating this matter because this law emerged in 1955, where economic conditions in Indonesia were very dynamic. Therefore BAPEPAM is obliged to conduct a legal analysis concerning law enforcement and legal certainty related to the capital market.

The authority to conduct an investigation carried out by BAPEPAM in every case (violation of criminal law regulations) is regulated in the Criminal Procedure Code as stated in the provisions of Article 6 (paragraph 1) letter (b). which states: "Investigators are certain civil servants who are given special authority by law." [12]

Examination systems in the capital market are explained in Government Regulation No. 46 of 1995. BAPEPAM [12] will examine if:

- There are reports, notices or complaints from parties about violations of capital market regulations.

- If obligations are not fulfilled by parties who obtain permits, approvals or from registration from BAPEPAM or from other parties required to submit reports to BAPEPAM, and

- There are indications of violations of laws in the capital market.

B. Types of Criminal Acts in the Capital Market Sector

Law Number 8 of 1995 concerning the Capital Market (UUPM) [12] has regulated criminal acts on the capital market, including such as fraud, market manipulation and insider trading. In addition to also stipulating criminal offenses in the capital market, as for the provision of criminal sanctions for the perpetrators, there is a form of fines, imprisonment/confinement where the punishment is varied depending on the level of loss incurred. Of course, the heavier the violations committed, the greater and heavier the criminal sanctions or fines.

There are several details about the types of crime in the capital market world, namely:

\section{Deception}

What is meant by committing fraud is regulated according to UUPM Article 90 letter c. When compared with the Criminal Code Article 378 the maximum sentence is 4 years in prison for those found guilty of fraud. Whereas in KUHP Article 390 the threat of 
punishment is a maximum of 2 years and 8 months imprisonment.[7]

Any perpetrator found guilty of fraud in securities trading activities may be subject to imprisonment/fine.[7]

Article 378 of the Criminal Code, it states that fraud is an act to benefit oneself or another person in a way:

- Against the law

- Using fake names or fake dignity

- Craftiness

- A series of lies

- Persuading others to give up something in their possession, or to give debt, or write off receivables.

Therefore, in UUPM Article 90 [12] it is stated that every party conducting securities trading activities is prohibited from committing fraud or deceiving other parties either directly or indirectly and also in any way. Those with the intent to benefit or avoid harm to themselves or other parties.

2. Market Manipulation

In addition to fraud, there are also other criminal acts in the Capital Market Law, namely market manipulation. Provisions for market manipulation are regulated in Articles 91.92 and 93 UUPM [12].

\section{Insider Trading}

It can be concluded that the elements of insider trading are: the existence of securities trading, carried out by people in the company, the presence of inside information, inside information is not yet open to the public / not yet a public domain. The term insider trading is a term borrowed from unfair stock trading practices in the United States that are associated with the use of confidential information by company officials who, because of their position, can benefit because of the information.[8]

Insider trading contains several elements [9]:

- Securities trading

- Performed by people in the company

- Inside information

- Information is confidential

- This trade is motivated by information obtained

- $\quad$ Aim for profit

Following Article 100 of the Capital Market Law, BAPEPAM has the authority to examine any party suspected of being involved in a violation of the Capital Market Law and/or its implementing regulations. In addition to BAPEPAM based on the Capital Market Law provisions, in the event of a crime in the capital market,
OJK can also conduct an examination or investigation on any party suspected of violating the capital market or capital market crime.[10]

C. Other Measures categorized as Capital Market Crimes In addition to the crimes discussed above, the UUPM explained several other actions included in the crimes in the capital market that could be threatened with criminal offenses, namely:

1. Every party without permission, approval or registration carries out activities in the capital market as:

- Mutual Fund Company

- Public Company

- Investment Advisor

- Custodian Service Provider

- Securities Administration Bureau

- Trustee

- Clearing Guarantee Institution or Depository and Settlement Institution

- Capital Market Supporting Professionals such as Accountants, Legal Consultants, Appraisers, Notaries, and other professions determined by the government

2. Investment Managers and Affiliated Parties who receive compensation from other parties in any form, directly or indirectly, for buying or selling securities.

- Issuers or Public Companies make a public offering but do not submit a registration statement or the registration statement has not been declared effective by BAPEPAM [12].

- Anyone who commits fraud, misleads BAPEPAM, removes, destroys, changes, obscures, hides, or falsifies records from parties who obtain permission, approval and registration from BAPEPAM [12].

- Any party who directly or indirectly influences another party to violate the UUPM articles is threatened with criminal offenses as determined in Articles 103-107 [12]

- Every crime or other actions included in crime in the capital market, Law no. 8 of 1995 concerning Capital Markets threatening imprisonment for 3 to 10 years and a fine of Rp. 5,000,000,000 (five billion rupiah) to $\mathrm{Rp}$. 15,000,000,000 (fifteen billion rupiah). 


\section{CONCLUSIONS AND SUGGESTIONS}

\section{A. Conclusions}

The capital market has a strategic role in national development as a source of financing in the business world and a place for community investment, where entrepreneurs and the community can collaborate for the creation of economic stability in the business world. But in practice, some criminal acts and violations occur in the world of capital markets.

Crimes in the capital market are typical crimes committed by capital market players in capital market activities. The Indonesian government, through BAPEPAM, strives to overcome and prevent crime in the Indonesian capital market by various ways between disciplining and fostering capital market players as a preventive measure and resolving crime in the capital market sector as a repressive measure. Law Number 8 of 1995 concerning Capital Market [12] categorizes capital market crimes themselves including fraud, market manipulation, insider trading and other actions that fall into the category of crime in the capital market sector.

Following Article 100 of the Capital Market Law [12], BAPEPAM has the authority to examine any party suspected of being involved in a violation of the Capital Market Law and/or its implementing regulations. In addition to BAPEPAM based on the Capital Market Law provisions, in the event of a crime in the capital market, OJK can also conduct an examination or investigation on any party suspected of committing capital market violations or capital market crimes.

B. Suggestions

Due to the growing economic development in Indonesia, and the more people open their eyes to investment activities in the capital market, the existing regulations are a legal product in a long time. Then there needs to be a renewal related to the legal basis for crimes in the capital market so that it is relevant to developments in the community. Because the law is not only a means of social control and maintaining economic stability, but also the need for updates or better changes in society, to provide legal certainty.

\section{REFERENCES}

11 Imaniyati, Neni S., and Diana Wiyanti. "Perlindungan Hukum terhadap Investor dan Upaya BAPEPAM dalam Mengatasi Pelanggaran dan Kejahatan Pasar." Mimbar: Jurnal Sosial dan Pembangunan, vol. 16, no. 4, 200

[2] Mario W. Sutantoputra \& Sarmauli Simangunsong. Legal Due Diligence (LDD) \& Legal Opinion (LO) dalam Rangka Initial Public Offering (IPO). RajaGrafindo Persada : Depok. 2019.

[3] M. Irsan Nasarudin, S.H., Indra Surya, S.H., LL.M., Ivan Yustiavandana, S.H., LL.M., Arman Nefi, S.H., M.M., Adiwarman, S.H., S.Sos. Aspek Hukum Pasar Modal Indonesia. Kencana : Jakarta. 201

[4] Undang-Undang Dasar 1945 Hasil Amandemen \& Proses Amandemen UUD 1945 Secara Lengkap, Sinar Grafika, 2002.
[5] Lili Rasjidi dan Ira Rasjidi, Dasar-dasar Filsafat dan Teori Hukum, PT. Citra Aditya Bakti, Bandung, hlm. 58

[6] Soerjono Soekanto, Mustafa Abdullah, Sosiologi Hukum Dalam Masyarakat, CV. Rajawali, Jakarta, 1982.

[7] M. Irsan Nasarudin, S.H., Indra Surya, S.H., LL.M., Ivan Yustiavandana, S.H., LL.M., Arman Nefi, S.H., M.M., Adiwarman, S.H., S.Sos. Opcit. Hal 258

[8] M. Irsan Nasarudin, S.H., Indra Surya, S.H., LL.M., Ivan Yustiavandana, S.H., LL.M., Arman Nefi, S.H., M.M., Adiwarman, S.H., S.Sos. Aspek Hukum Pasar Modal Indonesia. Kencana : Jakarta. 2014,

[9] Edi Setiadi, Hukum Pidana Ekonomi, Yogyakarta : Graha Ilmu, 2010.

[10] Edi Setiadi, Hukum Pidana Ekonomi, Yogyakarta: Graha Ilmu, 2010.

[11] Irsan Nasarudin, Aspek Hukum Pasar Modal, Jakarta : Kencana, 2008.

[12] Republik Indonesia, UU No. 8 Tahun 1995 Tentang Pasar Modal, Pasal 101, dan UU No. 21 Tahun 2011 Tentang Otoritas Jasa Keuangan, Pasal 49.

[13] Dwipriyoko,E., Bon,ATB , \& Sukono, F. Enterprise Architecture Planning as New Generation Cooperatives Research Methods. In Journal of Physics: Conference Series (Vol. 1179, No. 1, p. 012094). IOP Publishing. 2019

[14] Dwipriyoko,E., Widjayani . Partial Business Process Reengineering in New Generation Cooperatives Enterprise Architecture Implementation. In Journal of Physics: Conference Series (Vol. 1477, ). IOP Publishing. 2020

[15] Widjajani, Nurjaman,R. The Framework of Strategic Agility in Small and Medium Enterprise. In Journal of Physics: Conference Series (Vol. 1477, ). IOP Publishing. 2020

[16] Gumilar,AC., Afrian,NFS., Pramiarsih,EE., Widjadjani, The Effect of Mathematics Learning With Improve Method to the Mathematical Representation Ability of Junior High School Students. In Journal of Physics: Conference Series (Vol. 1477, ). IOP Publishing. 2020

[17] Sutarman,E., Widjajani, Dwipriyoko,E. Effect of Additive Chemicals on Soil Characteristics. In Journal of Physics: Conference Series (Vol. 1477, ). IOP Publishing. 2020

[18] Ridha,MR., Pramiarsih,EE., Widjajani, The Use Of Geogebra Software In Learning Geometry Transformation To Improve Students' Mathematical Understanding Ability In Journal of Physics: Conference Series (Vol. 1477, ). IOP Publishing. 2020 